\title{
New Insights on Audit Quality
}

Ya-Fang Wang ${ }^{\dagger}$

Providence University, 200, Sec. 7, Taiwan Boulevard, Shalu Dist., Taichung City 43301, Taiwan

\begin{tabular}{l}
\hline ARTICLE INFO \\
\hline Article History \\
Received 12 February $2020 ;$ \\
Accepted 13 April 2020 \\
\hline JEL Classifications \\
M42
\end{tabular}
ABSTRACT

Purpose:

The mechanism of dual attestation system is to enhance audit quality through bonding legal liability of two signing partners. However, an intense debate regarding the retention or abolition of dual attestation system was discussed in recent years, because the amended Accountant Act have disputes over auditor's legal liabilities attributed to the Bardon and Rebar frauds. This study thus examines the audit quality of dual attestation system by exploring whether auditor locality and auditor tenure can affect audit quality simultaneously.

Design/methodology/approach:

This study investigates whether auditor locality and auditor tenure can affect audit quality simultaneously, using a regression model to examine my research issues. The sample is restricted to Taiwan's public listed companies of Big Four audit from 2002-2013 because data collection involves significant manual effort in reading individual auditor information of Big Four and searching lead/concurring auditor-client distance of Big Four. Financial data is obtained from Taiwan Economic Journal database (TEJ).

Finding:

I present evidence that audit quality is affected by auditor locality and auditor tenure, and differential portfolio of auditor locality and auditor tenure have different effects on audit quality under the dual attestation system.

Research limitations/implications:

This study has three limitations. First, the sample is limited to the clients of PwC, Deloitte, EY and KPMG because the required information for practice offices of lead and concurring

Keywords: audit quality; dual attestation; auditor locality; auditor tenure auditors is only available for Big 4. Second, although discretionary accruals is a noisy proxy for audit quality and it does not necessarily reflect actual audit quality, it is widely used in the literature to provide rich insights into audit quality. Three, sample size is limited because of insufficient data to compute discretionary accruals.

Originality/value:

This investigation extends previous research on audit quality by examining the geographic proximity and auditor-client relationship. Furthermore, this study contributes to the debate regarding the retention or abolition of dual attestation system.

\footnotetext{
1. Introduction

A series of high-profile accounting scandals in Taiwan (e.g., Procomp, Rebar, Infodisc, and Summit Computer) has caused substantial economic losses and eroded investor confidence in financial reporting reliability. These accounting scandals also have attracted the attention of regulators and market participants to the role of auditors in financial reporting and its audit quality. Understanding the determinants of audit quality with a focus on the role of auditors is especially important because auditors play an important role in safeguarding investor interests by providing effective audits and reasonable assurance on financial reporting. In particular, Taiwan has implemented dual attestation system to enhance audit quality by two auditors (lead and concurring auditors) review audit works to reduce audit risks and share the responsibility of financial assurance. This gives this study an opportunity to study whether and how audit quality is affected by individual auditor effects.

The discussion regarding audit quality and its determinants has received more research attention in recent years. Regarding audit quality research, prior studies focus on three key aspects, namely: auditor/audit firm (skepticism and independence); client (internal controls); and auditor-client relationship (auditor tenure). In this study, I extend prior

${ }^{\dagger}$ Corresponding Author: Ya-Fang Wang

Email: yfwang2@pu.edu.tw
}

DOI: $10.25103 /$ ijbesar.131.03 
literature and focus on the aspect of auditor-client relationship by highlighting that audit quality not only is affected by auditor-client relationship (duration), but by auditor locality (distance) and auditing environment (dual attestation system) to investigate my research issues. Most of prior research (Choi et al., 2014; DeFond and Zhang, 2014; Eshleman and Peng, 2014; DeFond et al., 2018) has focused on examining the effect of audit office specialisation and/or audit office size on audit quality, and found that larger audit firms and industry specialist provide higher audit quality because they have rich resources to plan audit engagements more completely and sophisticated audit experiences to perform audit engagements more prudently. Prior studies further have found that geographic advantages between the auditor's practicing office and the client's headquarter are more likely to bring a more efficient audit to their clients (Francis et al., 1999; Wallman, 1996), and then receive audit fee premiums (Ferguson et al., 2003; Francis, 2004). Moreover, geographic advantages of auditor locality help auditors understanding their clients and obtain more industry knowledge in performing audit programs (Francis and Yu, 2009; Choi et al., 2010; Reichelt and Wang, 2010; Choi et al., 2012; Francis et al., 2013; Francis and Michas, 2013; Chi et al., 2011). Therefore, geographic advantages of auditor locality seem to play an important role in audit programs and bring auditing information advantages to improve audit quality.

Mentioning the cooperation relationship between auditors and clients, prior auditing literature has documented that the long-term auditor-client relationship may impair auditor skepticism and independence because auditors are more familiar with their clients leading to the auditor building an excessive economic bond with the client (Dopuch et al., 2001; Deis and Giroux, 1992; Berton, 1991; U.S. Senate, 1977; Mautz and Sharaf, 1961). In contrast, some auditing literature has documented that long-term auditor-client relationship may improve audit quality because auditors are more likely to obtain better understanding of client conditions (Carcello and Nagy, 2004; Myers et al., 2003; Johnson et al., 2002; Geiger and Raghunandan, 2002; Chen et al., 2008; Chi et al., 2009). Therefore, there is still confusion and debate on whether long-term auditor-client relationship improves or impairs audit quality. However, prior studies might ignore that inconclusive results might affect by the combined effects of cooperation relationship (duration) and auditor locality (distance), not only single factor.

In Taiwan, performing a dual attestation system in the auditing environment is special. A dual attestation system indicates that lead and concurring auditors sign their names in the audit report published and share the responsibility of financial assurance. In fact, a dual attestation system is focused on the individual auditor (lead and concurring auditors), not on audit firms. This study thus conjectures that the individual auditor (lead and concurring auditors) is close related to audit quality. As discussed above, the auditor-client relationship not only is affected by cooperation relationship (duration) and auditor locality (distance), but by the individual auditor (lead and concurring auditors). Taiwan's auditing environment gives this study an opportunity to explore on whether audit quality is affected by cooperation relationship (duration), auditor locality (distance), and the individual auditor (lead and concurring auditors).

Prior studies (Manry et al., 2008; Myers et al., 2003) indicate that the level of discretionary accruals is related to audit quality and thus using discretionary accruals as the proxy for audit quality is reasonably well specified. Several studies also indicate that discretionary accruals is highly associated with audit quality proxies. For example, auditor litigation (Heninger, 2001), qualified audit opinions (Bartov et al., 2000), auditor's reporting failures (Geiger and Raghunandan, 2002), aggressive audit style (Becker et al., 1998; Francis and Krishana, 1999), and auditor changes (DeFond and Subramanyam, 1998) are positively associated with discretionary accruals. Therefore, this study adopts discretionary accruals as a proxy for audit quality and includes various control variables in the research model that could affect audit quality. The research model (1) is presented as follows:

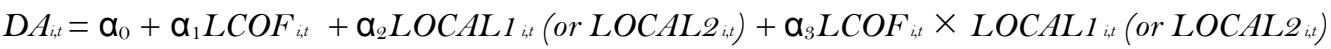

$$
\begin{aligned}
& +\mathrm{\alpha}_{4} G R O W T H_{i, t}+\mathrm{\alpha}_{5} R O A_{i, t}+\mathrm{\alpha}_{6} L E V_{i, t}+\mathrm{\alpha}_{7} C R_{i, t}+\mathrm{\alpha}_{8} M B_{i, t}+\mathrm{\alpha}_{9} M V E_{i, t} \\
& +\mathrm{\alpha}_{10} \text { OPINION }_{i, t}+\mathrm{\alpha}_{11} \text { TENURE }_{i, t}+\delta \text { YEAR } R_{i, t}+\varphi \operatorname{IND}_{i, t}+\varepsilon_{i, t}
\end{aligned}
$$

where:

$D A \quad$ = discretionary accruals from the modified Jones model (1991);

LCOF $\quad=1$ if the lead and concurring auditor come from different practice offices, and o otherwise;

LOCAL1 = 1 if the city of practice office of lead auditor and client are different, and o otherwise;

LOCAL2 = 1 if the city of practice office of concurring auditor and client are different, and o otherwise;

GROWTH= percentage growth in sales;

ROA = net income divided by total assets;

LEV = long-term debt divided by total assets;

CR $\quad=$ current assets divided by total assets;

$M B \quad$ = market value divided by book value of equity;

MVE = the natural log of market value of equity;

OPINION = 1 if the company receives a modified unqualified audit opinion, and o otherwise; 
TENURE = the natural log of the auditor's tenure;

TEAR = fiscal year dummies;

IND $\quad$ dummy variables controlling for industries.

In Eq. (1), this study includes the test variable $(L C O F)$ and a series of control variables, and the dependent variables $(D A)$ as described above. Dependent variable, $D A$, is discretionary accruals from the modified Jones model (1991). Test variable, $L C O F$, is a dummy variable that takes the value of 1 when the lead and concurring auditor come from different practice offices. This study further includes two test variables: LOCAL1 and LOCAL2 are dummy variables that takes the value of 1 when the city of practice office of lead/concurring auditor and client are different. Additionally, this study includes various control variables in the research model that could affect audit quality (Morsfield and Tan, 2006; Hribar and Nichols, 2007; Chi et al., 2011; Butler et al., 2004; Myers et al., 2003). For example, including GROWTH, MB, ROA, LEV, CR, and $M V E$ control for firm's financial conditions. This study also follows prior research (Stice, 1991; Heninger, 2001; Butler et al., 2004) to include audit opinion (OPINION) and auditor tenure (TENURE). Finally, including year and industry dummy variables ( $Y E A R$ and IND) control for possible variation across years and industries.

\section{Empirical Result and Analysis}

\subsection{Sample Description}

Using publicly traded firms listed on the Taiwan Stock Exchange (TWSE) from 2002 to 2013, this study examines the audit quality of dual attestation system by exploring whether auditor locality (distance) and auditor tenure (duration) can affect audit quality simultaneously. Following prior studies (Kothari et al., 2005; Teoh et al., 1998), this study created a matched sample by matching each firm-year LCOF observation in the sample with another Non$L C O F$ from the same industry classification and year with the closest firm size in the current year to control for systematic temporal and cross-sectional differences. The final sample comprised 463 firms that the lead and concurring auditor come from same practice offices and 463 firms that the lead and concurring auditor come from different practice offices.

Table 1 is the sample description. Panel A reports descriptive statistics and shows that the mean value of $D A$ for the LCOF (Non-LCOF) Group is -0.003 (-0.035), showing that LCOF Group has higher audit quality than NonLCOF Group. The mean value of OPINION for the LCOF (Non-LCOF) Group is 0.644 (0.575), showing that LCOF Group seems more likely to receive an unfavorable opinion than Non-LCOF Group. The mean value of TENURE for the LCOF (Non-LCOF) Group is 2.401 (2.304), showing that LCOF Group has a long-tenured auditor-client relationship than Non-LCOF Group. Additionally, the matched sample appears effective in forming a balanced sample of LCOF and Non-LCOF companies, as most control variables are insignificantly different between the two company types, except OPINION and TENURE. Panel B presents Pearson correlation coefficients for all control variables considered. The correlations between control variables are mostly very low, except for those between $G R O W T H$ and $M B$ (0.353). This study also computes variance inflation factors (VIFs) for all models and find that none of the VIFs exceeds 10 , suggesting that multicollinearity is not problematic in this study.

Table 1 Sample Description

\begin{tabular}{|c|c|c|c|c|c|c|}
\hline \multicolumn{7}{|c|}{ Panel A: Descriptive Statistics } \\
\hline & \multicolumn{2}{|c|}{ LCOF Group a $(\mathrm{Obs}=463)$} & \multicolumn{2}{|c|}{ Non-LCOF Group $(\mathrm{Obs}=463)$} & \multicolumn{2}{|c|}{ Test of Differences } \\
\hline Variable $^{b}$ & Mean & Median & Mean & Median & t-test ${ }^{c}$ & Wilcoxon \\
\hline$D A$ & -0.003 & 0.001 & -0.035 & -0.034 & $2.852^{* * * *}$ & $2.953^{* * *}$ \\
\hline GROWTH & 0.082 & 0.041 & 0.087 & 0.044 & -0.244 & -0.134 \\
\hline$R O A$ & 0.107 & 0.095 & 0.107 & 0.096 & 0.049 & -0.094 \\
\hline$L E V$ & 0.088 & 0.046 & 0.079 & 0.044 & 1.394 & 1.063 \\
\hline$C R$ & 2.426 & 1.832 & 2.435 & 1.878 & -0.055 & -0.457 \\
\hline$M B$ & 1.619 & 1.229 & 1.630 & 1.273 & -0.070 & -0.575 \\
\hline$M V E$ & 15.434 & 15.289 & 15.321 & 15.101 & 1.212 & 1.577 \\
\hline OPINION & 0.644 & 1.000 & 0.575 & 1.000 & $2.158^{* *}$ & $2.154^{* *}$ \\
\hline TENURE & 2.401 & 2.485 & 2.304 & 2.398 & $2.112^{* *}$ & $2.296^{* *}$ \\
\hline \multicolumn{7}{|c|}{ Panel B: Pearson Correlation Matrix } \\
\hline Variable & GROWTH & $R O A$ & $L E V$ & $M B$ & $M V E$ & OPINION \\
\hline$R O A$ & 0.162 & & & & & \\
\hline$L E V$ & 0.073 & -0.117 & & & & \\
\hline$C R$ & -0.057 & 0.122 & -0.210 & & & \\
\hline
\end{tabular}




\begin{tabular}{|c|c|c|c|c|c|c|c|}
\hline$M B$ & 0.353 & 0.297 & 0.011 & 0.033 & & & \\
\hline$M V E$ & 0.055 & -0.026 & 0.285 & -0.158 & -0.117 & & \\
\hline OPINION & -0.001 & 0.011 & 0.062 & -0.056 & 0.007 & 0.190 & \\
\hline TENURE & -0.118 & -0.054 & 0.071 & -0.071 & -0.133 & 0.269 & 0.025 \\
\hline
\end{tabular}

\subsection{Empirical Result}

\section{Auditor Locality}

Table 2 reports sample distributions by lead and concurring auditor locality. Panel A shows that firms with lead auditor locality have the highest percentages (66.41\%) while firms without lead auditor locality have the lowest percentages (33.59\%). Panel B also shows that firms with concurring auditor locality have the highest percentages $(60.15 \%)$ while firms without concurring auditor locality have the lowest percentages (39.85\%). These results imply that auditor locality may play a moderating factor in the degree of audit quality when there is a geographic relationship between auditees and their auditors. Panel C presents the results of OLS regression analyses of auditor locality and their audit quality. As shown in Column (1) of Panel C, the coefficient of LCOF is positively significant $(t=3.18, \mathrm{p}<0.01)$, indicating that the degree of audit quality is low when there is no geographic relationships between lead and concurring auditors. This finding implies that geographic relationships can improve audit quality because it is a very crucial and significant element in auditing communication. Results show that LOCAL1 in Column (1) is significantly positive $(t=2.23, \mathrm{p}<0.05)$, indicating that firms have a lower audit quality when there is no geographic relationships with their lead auditors. The coefficient of LOCAL2 in Column (2) is insignificant $(t=1.58)$. Altogether, these results reveal that geographic relationships among lead auditors, concurring auditors, and clients help to communicate and bridge differences of auditing processes. This study further includes $L C O F$ and its interaction with LOCAL1 in Column (1) and LCOF and its interaction with LOCAL2 in Column (2). Results show that $L C O F \times L O C A L 1$ in Column (1) is significantly negative $(t=-1.82)$, whereas LCOF $\times$ LOCAL2 in Column (2) is insignificant $(t=-1.18)$.

Table 2 Auditor Locality and Audit Quality

\begin{tabular}{|c|c|c|c|}
\hline \multicolumn{4}{|c|}{ Panel A : Distribution by $L C O F$ Group and $L O C A L 1$ Group } \\
\hline & Non-LOCAL1 Group ${ }^{b}$ & LOCAL1 Group & Total \\
\hline $\mathrm{LCOF}_{\text {Group }}{ }^{\mathrm{a}}$ & 260 & 203 & 463 \\
\hline Non-LCOF Group & 355 & 108 & 463 \\
\hline Total & $615(66.41 \%)$ & $311(33.59 \%)$ & \\
\hline \multicolumn{4}{|c|}{ Panel B : Distribution by $L C O F$ Group and $L O C A L \mathcal{Q}$ Group } \\
\hline & Non-LOCAL2 Group ${ }^{c}$ & LOCAL2 Group & Total \\
\hline LCOF Group & 187 & 276 & 463 \\
\hline Non-LCOF Group & 370 & 93 & 463 \\
\hline Total & $557(60.15 \%)$ & $369(39.85 \%)$ & \\
\hline
\end{tabular}

Panel C : Regression Analysis

\begin{tabular}{|c|c|c|c|c|c|}
\hline \multirow[b]{2}{*}{ Variable $^{\mathrm{d}}$} & \multirow[b]{2}{*}{ Pred. Sign } & \multicolumn{2}{|c|}{$(1)$} & \multicolumn{2}{|c|}{$(2)$} \\
\hline & & Coef. & $t$-value $\mathrm{e}^{\mathrm{e}}$ & Coef. & $t$-value \\
\hline CONSTANT & & -0.8276 & $-14.00^{* * * *}$ & -0.8221 & $-13.80^{* * * *}$ \\
\hline$L C O F$ & $+1-$ & 0.0356 & $3.18^{* * * *}$ & 0.0313 & $2.5 \mathrm{O}^{* *}$ \\
\hline LOCAL 1 & $+/-$ & 0.0343 & $2.23^{* *}$ & & \\
\hline$L C O F \times L O C A L 1$ & $+/-$ & -0.0366 & $-1.82^{*}$ & & \\
\hline LOCAL2 & $+1-$ & & & 0.0259 & 1.58 \\
\hline$L C O F \times{ }_{L O C A L 2}$ & $+/-$ & & & -0.0250 & -1.18 \\
\hline GROWTH & - & -0.0396 & $-2.49^{* * * *}$ & -0.0393 & $-2.47^{* * * *}$ \\
\hline$R O A$ & - & -0.4280 & $-6.30^{* * * *}$ & -0.4257 & $-6.24^{* * *}$ \\
\hline$L E V$ & + & 0.0063 & 0.12 & 0.0094 & 0.18 \\
\hline
\end{tabular}




\begin{tabular}{|c|c|c|c|c|c|}
\hline$C R$ & + & 0.0160 & $7.87^{* * * *}$ & 0.0160 & $7.82^{* * * *}$ \\
\hline$M B$ & - & -0.0057 & $-2.45^{* * *}$ & -0.0057 & $-2.45^{\text {***** }}$ \\
\hline$M V E$ & + & 0.0563 & $15.12^{* * * *}$ & 0.0562 & $14.97^{* * * *}$ \\
\hline OPINION & + & 0.0067 & 0.67 & 0.0070 & 0.70 \\
\hline TENURE & $+/-$ & -0.0130 & $-1.82^{*}$ & -0.0134 & $-1.87^{*}$ \\
\hline YEAR \& IND & & \multicolumn{2}{|c|}{ Included } & \multicolumn{2}{|c|}{ Included } \\
\hline Adj. $R^{2}$ & & \multicolumn{2}{|c|}{$38.51 \%$} & \multicolumn{2}{|c|}{$38.34 \%$} \\
\hline Obs & & \multicolumn{2}{|c|}{926} & \multicolumn{2}{|c|}{926} \\
\hline $\begin{array}{l}\text { a } L C O F(\text { Non- } L C O F \\
\text { b } L O C A L 1 \text { (Non- } L O \\
\text { c LOCAL2 (Non- } L O \\
\text { d The definition of } \\
\text { practice offices, and } \\
\text { LOCAL2 }=1 \text { if the } \\
\text { accruals from the m } \\
\text { assets; } L E V=\text { long-t } \\
\text { book value of equity } \\
\text { unqualified audit op } \\
\text { winsorized at the firs } \\
\text { e Asterisks*, }{ }^{* *}, * * * i n d\end{array}$ & $\begin{array}{l}\text { es the leac } \\
\text { denotes th } \\
\text { denotes th } \\
\text { eported it } \\
\text { OCALA } 1= \\
\text { ce office } \\
\text { model (1s } \\
\text { ded by tot } \\
\text { natural } \\
\text { otherwise } \\
\text { centiles. }\end{array}$ & $\begin{array}{l}\text { urring audito } \\
\text { actice office } \\
\text { actice office } \\
\text { are: } L C O F \\
\text { y of practice } \\
\text { ng auditor a } \\
W T H=\text { per } \\
C R=\text { current } \\
\text { rket value of } \\
E=\text { the nat } \\
\text { and } 0.01 \text { leve }\end{array}$ & $\begin{array}{l}\text { e from differ } \\
\mathrm{d} \text { auditor an } \\
\text { icurring aud } \\
\text { if the lead } \\
\text { of lead aud } \\
\text { ient are diffe } \\
\text { ge growth ir } \\
\text { ts divided by } \\
\text { ity; OPINIO } \\
\text { og of the a } \\
\text { spectively. }\end{array}$ & $\begin{array}{l}\text { practice offi } \\
\text { different (sa } \\
\text { ient are differ } \\
\text { ring auditor } \\
\text { ient are diffe } \\
\text { O otherwise } \\
A=\text { net inc } \\
\text { ts; } M B=\text { ma } \\
\text { the company } \\
\text { nure. All co }\end{array}$ & $\begin{array}{l}\text { same). } \\
\text { e from different } \\
\text { and o otherwise; } \\
=\text { discretionary } \\
\text { divided by total } \\
\text { value divided by } \\
\text { eives a modified } \\
\text { les variables are }\end{array}$ \\
\hline
\end{tabular}

\section{Auditor-Client Relationship}

As discussed above, empirical results show that audit quality is affected by geographic relationships particularly when there is no geographic relationships with lead auditors. Additionally, audit quality not only is affected by geographic relationships, but also effects of the auditor-client relationship (e.g., auditor tenure). Prior research has explored two competing views concerning the influence of auditor tenure on audit quality. For example, several studies (Farmer et al., 1987; Brody and Moscove, 1998; Davis et al., 2002) have shown that long audit tenure might reduce auditor independence and professional skepticism, thereby reducing audit quality. On the other hand, some studies (St. Pierre and Anderson, 1984; Geiger and Raghunandan, 2002; Myers et al., 2003; Carey and Simnett, 2006; Chen et al., 2008; Gul et al., 2009; Chi et al., 2009) have shown that long auditor tenure might increase auditor independence and competence because the auditor's client-specific knowledge increases over the years, thereby increasing audit quality. Therefore, there is no systematic evidence on whether auditor-client relationship affects audit quality. This study further includes the factor of lead auditor-client relationship in following empirical analyses. Table 3 presents empirical results. First, I partition the sample into two subsamples based on lead auditor tenure, namely the long term ( $\geqq 5$ consecutive financial years) and short term $(<5$ consecutive financial years) auditor-client relationship subsamples. Panel A of Table 3 shows that the coefficients of LCOF, LOCAL 1 and LCOF $\times$ LOCAL 1 in Column (2) are significantly positive and negative $(t=3.24, t=1.91$ and $t=-1.97$, respectively), whereas all of the coefficients of $L C O F$, LOCAL1 and LCOF $\times$ LOCAL 1 in Column (1) are insignificant. Second, I partition the sample into two subsamples based on lead and concurring auditor tenure, namely the close-knit (lead auditor tenure $>$ concurring auditor tenure) and alienated (lead auditor tenure < concurring auditor tenure) auditor-client relationship subsamples. Panel B of Table 3 shows that the coefficients of LCOF, LOCAL1 and LCOF $\times$ LOCAL1 in Column (2) are significantly positive and negative (t=5.18, $t=2.36$ and $t=-3.16$, respectively), whereas all of the coefficients of LCOF, LOCAL1 and $L C O F \times$ LOCAL 1 in Column (1) are insignificant.

Table 3 Considering the Auditor-Client Relationship

Panel A : Considering Auditor Rotation

\begin{tabular}{|c|c|c|c|c|c|}
\hline \multirow[b]{2}{*}{ Variable $^{\text {a }}$} & \multirow[b]{2}{*}{ Pred. Sign } & \multicolumn{2}{|c|}{$(1)$} & \multicolumn{2}{|c|}{ (2) } \\
\hline & & Coef. & $t$-value ${ }^{b}$ & Coef. & $t$-value \\
\hline CONSTANT & & -0.9433 & $-9.98^{* * * *}$ & -0.7638 & $-9.43^{* * * *}$ \\
\hline $\mathrm{LCOF}$ & $+1-$ & 0.0122 & 0.81 & 0.0542 & $3.24^{* * * *}$ \\
\hline LOCAL 1 & $+1-$ & 0.0265 & 1.24 & 0.0429 & $1.91^{*}$ \\
\hline$L C O F \times L O C A L 1$ & $+/-$ & -0.0196 & -0.71 & -0.0573 & $-1.97^{* *}$ \\
\hline GROWTH & - & -0.0298 & -1.22 & -0.0525 & $-2.44^{* *}$ \\
\hline$R O A$ & - & -0.3480 & $-3.61^{* * * *}$ & -0.5113 & $-5.09^{* * * *}$ \\
\hline$L E V$ & + & 0.0133 & 0.19 & 0.0256 & 0.35 \\
\hline$C R$ & + & 0.0250 & $6.07^{* * *}$ & 0.0142 & $5.66^{* * * *}$ \\
\hline$M B$ & - & -0.0003 & -0.05 & -0.0057 & $-1.99^{* *}$ \\
\hline$M V E$ & + & 0.0610 & $11.29^{* * *}$ & 0.0545 & $10.57^{* * * *}$ \\
\hline OPINION & + & -0.0097 & -0.73 & 0.0188 & 1.28 \\
\hline
\end{tabular}




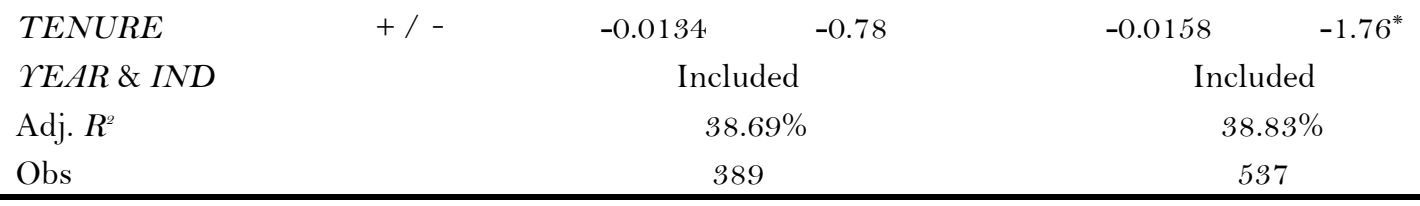

Panel B : Considering Auditor Tenure

$(1)$

(2)

\begin{tabular}{|c|c|c|c|c|c|}
\hline & & & & & \\
\hline Variable & Pred. Sign & Coef. & $t$-value & Coef. & $t$-value \\
\hline CONSTANT & & -0.8940 & $-11.60^{* * * *}$ & -0.7690 & $-8.24^{* * * *}$ \\
\hline $\mathrm{LCOF}$ & $+1-$ & -0.0095 & -0.66 & 0.0924 & $5.18^{* * *}$ \\
\hline LOCAL1 & $+1-$ & 0.0264 & 1.34 & 0.0566 & $2.36^{* *}$ \\
\hline$L C O F \times L O C A L 1$ & $+1-$ & -0.0022 & -0.09 & -0.0991 & $-3.16^{* * *}$ \\
\hline GROWTH & - & -0.0755 & $-3.64^{* * * *}$ & -0.0313 & -1.15 \\
\hline$R O A$ & - & -0.3466 & $-3.83^{* * *}$ & -0.4432 & $-3.65^{* * *}$ \\
\hline$L E V$ & + & -0.0333 & -0.51 & 0.1455 & $1.77^{* *}$ \\
\hline$C R$ & + & 0.0171 & $5.06^{* * * *}$ & 0.0148 & $5.56^{* * *}$ \\
\hline$M B$ & - & 0.0136 & $2.10^{* *}$ & -0.0147 & $-3.19^{* * *}$ \\
\hline$M V E$ & + & 0.0586 & $12.40^{* * *}$ & 0.0534 & $9.05^{* * *}$ \\
\hline OPINION & + & -0.0056 & -0.45 & 0.0185 & 1.14 \\
\hline TENURE & $+/-$ & -0.0166 & $-1.39^{*}$ & -0.0076 & -0.80 \\
\hline YEAR \& IND & & Ino & & & \\
\hline Adj. $R^{2}$ & & & & & \\
\hline Obs & & & & & \\
\hline $\begin{array}{l}\text { a The definition of the } \\
\text { practice offices, and } 0 \text { o } \\
D A=\text { discretionary acc } \\
\text { divided by total assets; } \\
\text { value divided by book } \\
\text { modified unqualified au } \\
\text { are winsorized at the fir } \\
\text { b Asterisks", **, ****indica }\end{array}$ & $\begin{array}{l}\text { ables reported } \\
\text { wise; } L O C A L 1 \\
\text { from the mod } \\
=\text { long-term } \\
\text { of equity; } M V \\
\text { pinion, and } 0 \\
\text { ad 99th percen } \\
\text { gnificance at th }\end{array}$ & $\begin{array}{l}\text { table are: } L \\
\text { e city of pra } \\
\text { es model }(1 \\
\text { ded by tota } \\
\text { natural log } \\
\text { e; TENUR } \\
.05 \text {, and } 0.0\end{array}$ & $\begin{array}{l}=1 \text { if the le } \\
\text { office of lead } \\
G R O W T H= \\
\text { ts; } C R=\text { cur } \\
\text { rket value of } \\
\text { he natural lo } \\
\text { ls, respective }\end{array}$ & $\begin{array}{l}\text { Irring audit } \\
\text { lient are dif } \\
\text { rrowth in sa } \\
\text { ided by tot } \\
I I O N=1 \text { if } \\
\text { or's tenure. }\end{array}$ & $\begin{array}{l}\text { e from dif } \\
\text { and } 0 \text { othe } \\
A=\text { net i } \\
\text {; } M B=\mathrm{n} \\
\text { ppany rece } \\
\text { tinues var }\end{array}$ \\
\hline
\end{tabular}

\subsection{Additional Test (results are not tabled)}

To provide evidence on whether there is any potential association among auditor-client relationship (duration), auditor locality (distance) and measures of discretionary accruals conditional on whether discretionary accruals are income-increasing or income-decreasing, this study partitioned the sample into companies engaging in incomeincreasing vs. income-decreasing earnings management (Francis and Yu, 2009; Lamoreaux, 2016). After re-running the Table 2, empirical results show that $L C O F \times L O C A L 1$ is significantly negative, whereas $L C O F \times L O C A L 2$ is insignificant, no matter whether these companies engaging in income-increasing or income-decreasing earnings management. This study obtained substantially similar results to those documented in Table 2 . I further re-run the Table 3, empirical results show that $L C O F \times L O C A L 1$ is significantly negative in Columns (2) of Panels A and B. The empirical results are similar to those reported in previous sections. Additionally, the events of restatements and auditor changes may bias the measure of discretionary accruals, this study further excluded observations with restatements or auditor changes to re-run empirical analyses and obtained substantially similar results. Overall, the inference of empirical results did not change.

\section{Conclusion}

Empirical results imply that auditor locality may play a moderating factor in the degree of audit quality when there is a geographic relationship between auditees and their auditors, and the degree of audit quality is low when there is no geographic relationships between lead and concurring auditors. This finding implies that geographic relationships can improve audit quality because it is a very crucial and significant element in auditing communication. Altogether, these results reveal that geographic relationships among lead auditors, concurring auditors, and clients help to communicate and bridge differences of auditing processes. Additionally, empirical results reveal that lead auditors are more likely to engage in improvement of auditing processes and present a higher audit quality under short auditorclient relationship or lacking audit experience.

This study has three limitations. First, the sample is limited to the clients of PwC, Deloitte, EY and KPMG because the required information for practice offices of lead and concurring auditors is only available for Big 4. Second, although discretionary accruals is a noisy proxy for audit quality and it does not necessarily reflect actual audit quality, it is widely used in the literature to provide rich insights into audit quality (Bartov et al., 2000; Becker et 
al., 1998; DeFond and Subramanyam, 1998; Francis and Krishana, 1999; Heninger, 2001; Geiger and Raghunandan, 2002; Manry et al., 2008; Myers et al., 2003). Three, sample size is limited because of insufficient data to compute discretionary accruals.

\section{References}

Bartov E, Gul F A, Tsui J S L. Discretionary-accruals models and audit qualifications [J]. Journal of Accounting and Economics, 2000, 30 (December): 421-452.

Becker C L, DeFond M L, Jiambalvo J J, Subramanyam K R. The effect of audit quality on earnings management [J]. Contemporary Accounting Research, 1998, 15 (Spring): 1-24.

Berton L. GAO weighs auditing plan for big banks [M]. Wall Street Journal, 1991, (March).

Brody R G, Moscove S A. Mandatory auditor rotation [J]. National Public Accountant, 1998, 43 (3): 32-36.

Butler M, Leone A J, Willenborg M. An empirical analysis of auditor reporting and its association with abnormal accruals [J]. Journal of Accounting and Economics, 2004, 37 (June): 139-165.

Carcello J V, Nagy A. Audit firm tenure and fraudulent financial reporting [J]. Auditing: A Journal of Practice and Theory, 2004, 23(2): 55-69.

Carey P, Simnett R. Audit partner tenure and audit quality [J]. The Accounting Review, 2006, 81 (3): 653-676.

Chen C Y, Lin C J, Lin Y C. Audit partner tenure, audit firm tenure, and discretionary accruals: Does long auditor tenure impair earnings quality? [J]. Contemporary Accounting Research, 2008, 25 (2): 415-445.

Chi H Y, Chin C L. Firm versus partner measures of auditor industry expertise and effects on auditor quality [J]. Auditing: A Journal of Practice and Theory, 2011, 30 (2): 201-229.

Chi W C, Huang H C, Liao Y H, Xie H. Mandatory audit partner rotation, audit quality, and market perception: Evidence from Taiwan [J]. Contemporary Accounting Research, 2009, 26 (2): 359-391.

Choi J H, Kim J B, Qiu A, Zang Y. Geographic proximity between auditor and client: How does it impact audit quality? [J]. Auditing: A Journal of Practice and Theory, 2012, 31(2): 43-72.

Choi J H, Kim F, Kim J B, Zang Y. Audit office size, audit quality, and audit pricing [J]. Auditing: A Journal of Practice and Theory, 2010, 29 (1): 73-97.

Davis L R, Soo B, Trompeter G. Auditor tenure, auditor independence and earnings management [R]. Working paper, 2002, Boston College.

DeFond M, Francis J, Hallman N. Awareness of SEC enforcement and auditor reporting decisions [J]. Contemporary Accounting Research, 2018, 35: 277-313.

DeFond M, Subramanyam K. Auditor changes and discretionary accruals [J]. Journal of Accounting and Economics, 1998, 25: 3567.

DeFond M, Zhang J. A review of archival auditing research [J]. Journal of Accounting and Economics, 2014, 58: 275-326.

Deis D, Giroux G. Determinants of audit quality in the public sector [J]. The Accounting Review, 1992, 67 (3): $462-479$.

Dopuch N R, King R, Schwartz R. An experimental investigation of retention and rotation requirements [J]. Journal of Accounting Research, 2001, 39: 93-117.

Eshleman J, Peng G. Do Big 4 auditors provide higher audit quality after controlling for the endogenous choice of auditor? [J]. Auditing: A Journal of Practice and Theory, 2014, 33: 197-219.

Farmer T A, Rittenberg L E, Trompeter G M. An investigation of the impact of economic and organizational factors on auditor independence [J]. Auditing: A Journal of Practice and Theory, 1987, 7 (1): 1-14.

Ferguson A, Francis J R, Stokes D J. The effects of firm-wide and office-level industry expertise on audit pricing [J]. The Accounting Review, 2003, 78 (2): 429-449.

Francis J. What do we know about audit quality? [J]. The British Accounting Review, 2004, 36: 345-368.

Francis J R, Krishnan J. Accounting accruals and auditor reporting conservatism [J]. Contemporary Accounting Research, 1999,16 (Spring): 135-165.

Francis J, Michas P N. The contagion effect of low-quality audits [J]. The Accounting Review, 2013, 88 (2): 521-552.

Francis J R, Michas P N, Seavey S. Does audit market concentration harm the quality of audited earnings? Evidence from audit markets in 42 countries [J]. Contemporary Accounting Research, 2013, 30 (1): 325-355.

Francis J R, Stokes D J, Anderson D. City markets as a unit of analysis in audit research and the re-examination of big 6 market shares [J]. Abacus, 1999, 35 (2): 185-206.

Francis J R, Yu M. The effect of big 4 offices on audit quality [J]. The Accounting Review, 2009, 84 (5): 1521-1552.

Geiger M A, Raghunandan K. Auditor tenure and audit reporting failures [J]. Auditing: A Journal of Practice and Theory, 2002, 21(1): 67-78.

Gul F A, Fung S Y K, Jaggi B L. Earnings quality: Some evidence on the role of auditor tenure and auditors' industry expertise [J]. Journal of Accounting and Economics, 2009, 47 (3): 265-287.

Heninger W. The association between auditor litigation and abnormal accruals [J]. The Accounting Review, 2001, 76 (1): 111-126.

Hribar P, Nichols D C. The use of unsigned earnings quality measures in tests of earnings management [J]. Journal of Accounting Research, 2007, 45: 1017-1053.

Johnson V, Khurana I K, Reynolds J K. Audit-firm tenure and the quality of financial reports [J]. Contemporary Accounting Research, 2002, 19 (4): 637-660.

Kothari S P, Leone A J, Wasley C E. Performance matched discretionary accrual measures [J]. Journal of Accounting and Economics, 2005, 39: 163-197.

Lamoreaux P. T. Does PCAOB inspection access improve audit quality? An examination of foreign firms listed in the United States [J]. Journal of Accounting and Economics, 2016, 61(2-3): 313-337.

Manry D L, Mock T J, Turner J L. Does increased audit partner tenure reduce audit quality? [J] Journal of Accounting Auditing and Finance, 2008, 23 (4): 553-572.

Mautz R K, Sharaf H A. The philosophy of auditing [M]. American Accounting Association, Sarasota FL, 1961. 
Morsfield S G, Tan C E L. Do venture capitalists influence the decision to manage earnings in initial public offerings? [J]. The Accounting Review, 2006, 81: 1119-1150.

Myers J, Myers L, Omer T. Exploring the term of the auditor-client relationship and the quality of earnings [J]. The Accounting Review, 2003, 78 (3): 779-799.

Reichelt K, Wang D. National and office-specific measures of auditor industry expertise and effects on audit quality [J]. Journal of Accounting Research, 2010, 48 (3): 647-686.

St. Pierre K, Anderson J. An analysis of factors associated with lawsuits against public accountants [J]. The Accounting Review, 1984, 59 (1): 242-263.

Stice J. Using financial and market information to identify pre-engagement factors associated with lawsuits against auditors [J]. The Accounting Review, 1991, 66 (July): 516-553.

Teoh S H, Welch I, Wong T J. Earnings Management and the post-issue performance of seasoned equity offerings [J]. The Journal of Financial Economics, 1998, 50: 63-99.

U.S. Senate. Improving the accountability of publicly owned corporations and their auditors. Prepared by the subcommittee on Reports, Accounting, and Management of the Committee on Governmental Affairs [M]. Government Printing Office, Washington DC, 1977.

Wallman S. The future of accounting, Part III: Reliability and auditor independence. Accounting Horizons, 1996, 10 (4): $76-97$.

This is an Open Access article distributed under the terms of the Creative Commons Attribution Licence

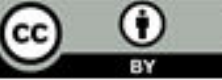

